\title{
Peran Parenting Orangtua Dalam Perspektif Pendidikan Kristen di Era Digital
}

\author{
Tri Astuti Yeniretnowati \\ Sekolah Tinggi Teologi Ekumene, Jakarta \\ triastutiyeniretnowati2015@gmail.com \\ Yakub Hendrawan Perangin Angin \\ Sekolah Tinggi Teologi Bethel The Way, Jakarta \\ yakub.hendrawan@sttbetheltheway.ac.id
}

\begin{abstract}
:
The digital era faced today is not easy, both for parents as well as for children of the digital generation. This sophisticated and very fast advancement of technology and information requires a change in the perspective of parents in carrying out their parenting duties and vocation so that they can remain adaptive in undergoing the changes that exist in this digital era while still being able to adhere to the principles of Christian education. The research method used is the library research method by analyzing textbooks and previous research journals, so that the formulation of parenting roles in the perspective of Christian education in the digital era is generated. The results of this study are: The role of successful parents in this digital era is at least two important things that must be highlighted and become the mainstay of parents in carrying out their parenting roles based on the perspective of Christian education, namely: becoming a model model that reflects the principles of life based on the Bible and those who second is to build good and strong relationships with children. Along with the times that are changing very quickly, as parents, they must also be harder, smarter, more insightful, and more thorough in facing the challenges of the digital era that affect children in this digital era by paying attention to several practical things. suggested by technology and information experts.
\end{abstract}

Keywords: parenting; parents; digital; christian education

\begin{abstract}
Abstrak:
Era digital yang dihadapi saat ini tidaklah mudah, baik untuk oarangtua juga untuk anakanak generasi digital. Kemajuan teknologi dan informasi yang canggih dan sangat cepat ini memerlukan perubahan perspektif dari para orangtua dalam menjalankan tugas dan panggilan parentingnya agar tetap dapat adaptif dalam menjalani perubahan yang ada di era digital ini namun tetap dapat berpegang teguh pada prinsip-prinsip pendidikan Kristen. Metode penelitian yang digunakan adalah metode penelitian kepustakaan (library research) dengan cara melakukan analisis buku teks dan jurnal penelitian sebelumnya, sehingga dihasilkan rumusan bagaimana peran parenting orangtua dalam perspektif pendidikan Kristen di era digital. Hasil dari penelitian ini adalah: Peran orangtua yang berhasil di era digital ini paling tidak dua hal penting yang harus ditonjolkan dan menjadi andalan orangtua dalam menjalankan peran parentingnya berdasarkan perspektif pendidikan Kristen, yaitu: menjadi model teladan yang mencerminkan prinsip-prinsip kehidupan berdasarkan Alkitab dan yang kedua adalah membangun hubungan relasi yang baik dan kuat dengan anak-anak. Seiring dengan perkembangan zaman yang terus berubah dengan sangat cepat, maka sebagai orang tua juga harus makin keras, makin cerdas, makin mawas, dan makin tuntas menghadapi persoalan tantangan era digital yang memengaruhi anak-anak yang ada dalam era digital ini
\end{abstract}


dengan memperhatikan beberapa hal praktis yang disarankan oleh para ahli teknologi dan informasi.

Kata kunci: parenting; orangtua; digital; pendidikan kristen

\section{Pendahuluan}

Teknologi memberikan kemudahan-kemudahan (facilities) dan kenyamanan (comfortable) dan bahkan menciptakan hiburan (entertainment). Ilmu pengetahuan dan teknologi dapat memakmurkan umat manusia, namun juga dapat menghancurkan umat manusia sehingga tidak berpaling dan bersyukur kepada Allah, melainkan melakukan berbagai tindakan dan perilaku yang jahat. ${ }^{1}$ Tidak dapat dipungkiri lagi dengan kemajuan teknologi informasi di zaman ini yang sudah semakin sangat canggih, terdapat juga banyak dampak negatif yang diakibatkannya. Anak-anak pun pasti terkena imbas dari kemajuan dan penggunaan teknologi informasi ini, baik melalui lingkungan sekolah, pergaulan, atau di lingkungan keluarga. Di satu sisi, penggunaan teknologi memang memberikan dampak positif dalam mempermudah dan membantu kegiatan sehari-hari, tetapi tidak dipungkiri ada banyak juga sisi negatif yang patut diwaspadai. ${ }^{2}$

Di seluruh dunia saat ini dalam era digital, dilaporkan kini terdapat 640 juta pengguna jaringan aktif dan ada 50 miliar foto yang diunggah ke dunia maya, sedangkan pengguna internet yang tercatat telah mencapai 2 miliar. Indonesia berada di urutan kedua pengguna Facebook terbanyak, dan urutan kesatu pengguna Tweeter. Sampai tahun 2020 diprediksi pengguna internet di Indonesia menjadi 175 juta. ${ }^{3}$ Ada beberapa masalah yang paling ditakuti akibat negatif dari gadget canggih, yaitu: kecantuan games on-line yang mempengaruhi prestasi belajar; gaya berbahasa gaul yang memusingkan dan budaya texting kepada orang tua yang dianggap kurang sopan; kegemaran berinternet yang membuat kurang bersosialisasi; juga masalah pornografi. ${ }^{4}$ Sebuah sumber berita di internet menyebutkan bagaimana seorang anak berusia dua belas tahun di Skotlandia memperkosa anak gadis tetangganya yang baru beusia sembilan tahun, karena dipicu oleh pengaruh pornografi di internet. Media Indonesia online, 4 Maret 2012, menyebutkan saat ini Indonesia sudah bertengger di peringkat satu dunia untuk mengakses pornografi. Hasil survei yang lebih mengkuatirkan bahwa mayoritas peangakses situs porno di Indonesia adalah anakanak SMP dan SMA. ${ }^{5}$ Pertumbuhan dan perkembangan seorang anak merupakan

${ }^{1}$ Arniwati and R. Budyarto, Dampak Teknologi Terhadap Kehidupan Rohani Anak Dan Remaja, 1st ed. (Malang: Gandum Mas, 2012), 19.

2 Paul Gunadi, Andrew Abdi Setiawan, and Lortha Gb. Mahanani, Memahami Remaja Dan Pergumulannya, 2nd ed. (Bandung: Visipress, 2015), 105.

${ }^{3}$ Hellen Chou Pratama, Cyber Smart Parenting, 1st ed. (Bandung: Visi Anugerah Bandung, 2012), 43.

4 Ibid., 58.

${ }^{5}$ Gunadi, Setiawan, and Mahanani, Memahami Remaja Dan Pergumulannya, 87. 
akibat dari berbagai faktor dalam kehidupannya. ${ }^{6}$ Tidak bisa diingkari, kehidupan keluarga merupakan tempat belajar seumur hidup dan kenyataan membuktikan bahwa keluarga yang sehat berdampak pada gereja, masyarakat, bahkan suatu bangsa. ${ }^{7}$ Kualitas kehidupan keluarga memengaruhi setiap aspek kehidupan yang lain, survei membuktikan bahwa sumber kebahagiaan terbesar adalah kehidupan keluarga, namun survei ini juga menemukan bahwa sumber frustasi dan kekecewaan terbesar dalam kehidupan manusia adalah menangani masalah keluarga. ${ }^{8}$ Keluarga masa kini berbeda dengan keluarga zaman dulu. Keluarga masa kini sudah banyak kehilangan fungsi dan arti.

Fungsi pendidikan sudah diserahkan pada lembaga-lembaga pendidikan, sehingga tugas orang tua dalam hal memperkembangkan segi intelek anak menjadi jauh lebih ringan. ${ }^{9}$ Peralatan yang serba modern dan mekanis, mengganti tenaga manusia dengan tenaga mesin dan listrik, sehingga tenaga manusia tidak lagi dibutuhkan. Keluarga mempunyai fungsi dalam bidang pendidikan sebagai sumber pendidikan utama, karena segala pengetahuan dan kecerdasan intelektuil manusia diperoleh pertama-tama dari orang tua dan anggota keluarganya sendiri. Keutuhan keluarga dan keserasian yang menguasai suasana di rumah merupakan salah satu faktor penting. Demikian pula tokoh ayah dan tokoh ibu sebagai pengisi hati nurani yang pertama harus melakukan tugas ini dengan penuh tanggung jawab dalam suasana kasih sayang antara pengasuh (orang tua) dengan yang diasuh (anak). Dalam bimbingan orang tua terhadap anaknya, jelas terlihat arti hubungan orang tua dan sumbangannya secara tidak langsung bagi kepentingan umum dan tercapainya masyarakat yang aman dan sentosa. Berbagai macam masalah umum tidak akan menjadi masalah dan tidak akan menyebabkan penderitaan bilamana ditangani seawal mungkin, yakni penanganan masalah dalam keluarga masing-masing. ${ }^{10}$

Taliziduhu Ndraha menjelaskan, tidak ada anak yang sulit. Yang ada hanyalah orangtua atau guru yang kesulitan menghadapi anak didiknya. Mengapa sulit? Karena orangtua tidak mempunyai pengetahuan dan skill yang cukup tentang anak dan cara mendidik anak. Para orangtua pada umumnya hanya meniru pola orangtua mereka. Bagaimana mereka dulunya diperlakukan, itulah yang diturunkan pada anak-anaknya. Tidak kurang, tidak lebih. Kecuali terjadi proses belajar ulang. ${ }^{11}$ Sehingga orangtua mempunyai kewajiban untuk mendidik anak-anak, hal ini tidak 1991), 25.

${ }^{6}$ H. Norman Wright, Menjadi Orangtua Yang Bijaksana, 2nd ed. (Yogyakarta: Andi Offset,

${ }^{7}$ Gunadi, Setiawan, and Mahanani, Memahami Remaja Dan Pergumulannya.

${ }^{8}$ H. Norman Wright and Gary J. Oliver, Raising Kids To Love Jesus, 3rd ed. (Yogyakarta: Gloria Graffa, 2013), 25.

${ }^{9}$ Ny. Singgih D. Gunarsa and Singgih D. Gunarsa, Psikologi Untuk Keluarga, 17th ed. (Jakarta: BPK Gunung Mulia, 2009), 2.

10 Ibid., 2-9.

${ }^{11}$ Roswitha Ndraha and Julianto Simanjuntak, Tidak Ada Anak Yang Sulit, 1st ed. (Yogyakarta: Andi Offset, 2009), xviii. 
dapat dibantah, karena itu orangtua bertanggungjawab untuk membesarkan dan mempersiapkan masa depan anak. Agar pendidikan berhasil, diperlukan situasi pendidikan yang baik dan bahan-bahan pendidikan serta metode mendidik yang tepat. ${ }^{12}$ Terlebih peran keluarga dalam hal ini orang tua harus menumbuhkan kesadaran dan pengertian serta memberikan masukan yang benar dalam mendidik Anak. ${ }^{13}$

Hal ini dikuatkan dengah hasil penelitian yang dilakukan oleh Lubis, Rosyida, dan Solikhatin, yang menyatakan bahwa orangtua harus memahami bahwasannya perangkat lunak dan media digital tidak dapat lepas sepenuhnya pada era sekarang ini, sehingga orangtua sebaiknya mengawasi anak dengan sebaik mungkin agar anak tidak salah menggunakan perangkat dan media digital tersebut. Hal ini membutuhkan ekstra tanggung jawab dari orangtua karena semakin hari semakin canggih perangkat dan media digital yang digunakan. Awal kesalahan pertama apabila orangtua menyerahkan keputusan menggunakan perangkat dan media digital sepenuhnya kepada anak, sehingga diperlukannya perilaku berkomunikasi internal keluarga untuk melindungi anak dari penggunaan perangkat digital dan paparan media digital. ${ }^{14}$ Penelitian lainnya menyimpulkan bagaimana sangat strategisnya peran orangtua dalam pendidikan bagi generasi digital yang berdampak pada meningkatnya spiritualitas dan moralitas anak yang sesuai dengan nilai-nilai Kristen di era digital, yaitu penelitian yang dilakukan oleh Boiliu. ${ }^{15}$ Berdasarkan permasalahan dan hasil penelitian inilah maka penulisan penelitian ini kembali menyoroti lebih luas ciri dari generasi digital dan dampak negative yang diakibatkannya serta bagaimana peran orang tua Kristen dalam menyikapi persoalanpersoalan ini.

\section{Metode}

Metode yang digunakan dalam penelitian ini adalah metode kualitatif dengan pendekatan kepustakaan (library research) dengan cara melakukan analisis buku teks. ${ }^{16}$ Sumber utama dari analisis adalah beberapa sumber relevan, hasil penelitian dari jurnal dan buku yang sesuai dengan judul penelitian. Semua sumber selanjutnya dianalisis dengan cara mencermati hubungan dan kecocokan dengan tema penelitian ini. Selanjutnya peneliti melakukan analisis yaitu dengan cara menganalisis tentang

12 R.I. Suhartin, Smart Parenting, 1st ed. (Jakarta: Libri, 2010), 6.

13 Yonatan Alex Arifianto, "Pentingnya Pendidikan Kristen Dalam Membangun Kerohanian Keluarga Di Masa Pandemi Covid-19," REGULA FIDEI: Jurnal Pendidikan Agama Kristen 5, no. 2 (2020): 94-106.

${ }^{14}$ Hairani Lubis, Afif Husniyatur Rosyida, and N H Solihatun, "Pola Asuh Efektif Di Era Digital," Plakat 1, no. 2 (2019): 102-109.

${ }^{15}$ Fredik Melkias Boiliu, "Pembelajaran Pendidikan Agama Kristen Dalam Keluarga Di Era Digital," TE DEUM (Jurnal Teologi Dan Pengembangan Pelayanan) 10, no. 1 (2020): 107-119.

16 Hamzah Amir, Metode Penelitian Kepustakaan, 1st ed. (Batu: Literasi Nusantara, 2020), 24. 
peran parenting orangtua dan era digital sebagai sebuah kerangka konsep peran parenting orangtua dalam perspektif pendidikan Kristen di era digital. Hasil analisis selanjutnya diuraikan secara deskriptif dan sistematis. Penelitian ini diharapkan memberikan bingkai teologis bagaimana peran parenting orangtua dalam perspektif pendidikan Kristen di era digital. ${ }^{17}$

\section{Hasil dan Pembahasan}

\section{Konsep Dunia Digital dan Generasi Digital}

Generasi digital tumbuh dengan kemajuan teknologi digital di dalam dunia super cepat, dimana mereka berubah secara dramatis serta terhubung dalam jaringan mendunia. Semua ada dalam jangkauan ujung jari-jari saja. Mengenali anak-anak dari sisi generasi mereka adalah memahami campuran dari berbagai hal dalam diri dan lingkungan hidupnya. Diantaranya: nilai-nilai yang disanjung, bagaimana mereka menyikapi hidup, kebiasaan dan perilakunya, medianya, teman sebaya, serta bahasanya. Kesemuanya ini bergabung membentuk cara pandang ataupun wawasan yang pada gilirannya mengarahkan hidup mereka. ${ }^{18}$

Generasi digital ini mempunyai tantangan yang tidak mudah bahkan dapat dikatakan lebih berat dari pada generasi sebelumnya. Tantangan itu antara lain: Pertama, Adanya konvergensi teknologi dan media menjadi hal yang mempunyai pengaruh sangat kuat terhadap generasi ini. Kedua, Adanya gerakan moralitas baru yang menggeser nilai-nilai kebenaran. Apa yang dulu dianggap kebenaran yang diterima secara mutlak sekarang menjadi relatif. Ketiga, Munculnya filosofi baru anti agama yang terintegrasi dalam berbagai program mengakibatkan meningkatnya atheis. $^{19}$

\section{Ciri Khas Generasi Digital}

Beberapa ciri khas dari generasi digital adalah: pertama, Ketergantungan yang besar terhadap teknologi dan kecanggihan penggunaanya. Kedua, pelahap media (mediavora), bahwa hampir tidak ada waktu yang dilalui tanpa menyentuh salah satu media digital yang ada saat ini, apakah itu Whats App, Tiktok, Facebook dan Smart Phone. Ketiga, multi-tasking atau kemampuan melakukan beberapa hal sekaligus. Kemampuan untuk memikirkan atau melakukan beberapa aktivitas di saat yang bersamaan. Keempat, hiper-koneksi, dorongan untuk terhubung dalam beberapa koneksi jaringan pada waktu yang sama. Kelima, toleran, bertumbuh di era

${ }^{17}$ Sonny Eli Zaluchu, "Struktur Artikel Untuk Jurnal Ilmiah Dan Teknik Penulisannya," in Strategi Menulis Jurnal Untuk Ilmu Teologi, ed. Sonny Eli Zaluchu, 1st ed. (Semarang: Golden Gate Publishing Semarang, 2020), 1-21.

18 Pratama, Cyber Smart Parenting, 37-38.

${ }^{19}$ Haryati, "Potret Anak Indonesia: Sebuah Tantangan Dan Peluang," in Teologi Anak Sebuah Kajian, ed. Tim KTAK Anak Bersinar Bangsa Gemilang Jaringan Peduli Anak Bangsa, 1st ed. (Jakarta: Literatur Perkantas, 2018), 28-29. 
keterbukaan, bersama dengan bangkitnya kesadaran pluralism dan relativisme, yang samakin berpengaruh menempa sikap toleran akan pandangan yang beragam. Keenam, tayang-langsung (real-time), karena selalu terkoneksi dan tumbuh dalam budaya keterbukaan, maka generasi ini sangat ekspresif dan komunikatif. Hampir tidak ada kesulitan untuk mencurahkan apa yang sedang dipikirkan dan dirasakan saat itu juga. Ketujuh, interaktif, membangun kehidupannya dengan topangan "jaringan" dan keperluan yang besar untuk dapat menjadi bagian dari komunitas media sosial tertentu yang diikutinya. ${ }^{20}$

\section{Tantangan dan Peluang Generasi Digital}

Begitu mudah, canggihnya dunia yang mereka jelajahi dan pada saat yang sama informasi yang diperoleh sangat membanjiri, sehingga mereka membutuhkan hikmat dari orang dewasa disekitarnya untuk bisa membantu mereka memaknai pengalaman dan keterpaparan ini secara tepat dan membangun. ${ }^{21}$ Pengaruh televisi terhadap perilaku anak-anak sangat nyata. Televisi mampu menyentuh anak-anak dan mempengaruhi pola pikir atau cara berpikir, pola rasa, serta pola tingkah laku atau perilaku juga nilai-nilai, karena televisi juga mempunyai kemampuan untuk menciptakan dan melestarikan stereotip-stereotif rasial, seksual, atau stereotip lainnya, baik melalui program maupun iklan. Artinya, televisi sebagai pranata sosial turut serta dalam membentuk mentalitas serta mengkonstruksi suatu kebudayaan dalam masyarakat. ${ }^{22}$

Berkaca kepada beberapa kasus yang melanda anak-anak yang dikendalikan oleh game online beberapa waktu lampau, yaitu: pertama, sharing ibu Linda California, anak bu linda sudah kelas 1 SMA dan tampaknya dia sudah kecanduan video game online. Diawali dari duduk terus di depan computer sambil dipasang infus pada tangannya untuk menyalurkan cukup cairan bergizi dan kafein sehingga dia tidak perlu makan atau tidur. Dia juga sudah mulai membohongi ayahnya, mama, dan gurunya tentang tugas sekolah untuk memaksimalkan aksesnya ke video game online. Dia mempunyai beberapa teman, yaitu gamer lainnya. Dulu nilainya semua A tetapi sekarang dia sering tidak lulus. Di satu pihak, ibu Linda senang karena anaknya tidak keluyuran, tidak tergoda narkoba, atau terlibat masalah lain. Tetapi ibu Linda merasa kuatir bahwa kehidupannya sangat sempit sehingga akan dirugikan karena obsesinya ini. Kemudian, bandingkan 9\% remaja di Singapura sudah ketagihan seperti penyakit terhadap game. Mereka main selama rata-rata 37,5 jam/minggu. Rata-rata $10 \%$ dari pemain game akan menjadi pecandu game. Di Korea Selatan, Seung Seob Lee

20 Pratama, Cyber Smart Parenting.

21 Ibid.

22 Singgih D. Gunarsa, Dari Anak Sampai Usia Lanjut: Bunga Rampai Psikologi Perkembangan, 3rd ed. (Jakarta: BPK Gunung Mulia, 2009), 169. 
bermain StarCraft selama lebih dari 50 jam berturut-turut di internet café dan akhirnya meninggal di sana pada umur 28 tahun karena serangan jantung. ${ }^{23}$

Dampak Positif

Dampak positif dari penggunaan teknologi digital cirinya adalah: pertama, canggih. Kedua, inovator. Ketiga, kreatif. Keempat, kolaborator. Kelima, entrepreneur. Lebih jauh lagi, media digital jika disiasati dengan tepat, menyediakan sebuah saluran komunikasi yang menghubungkan anggota keluarga tanpa kendala ruang dan waktu. ${ }^{24}$ Selanjutnya, Sari dan Bermuli dalam penelitian menyatakan bahwa, kehadiran era digital telah memberi dampak yang signifikan dalam dunia pendidikan mulai dari perubahan aktivitas pengajaran hingga cara belajar yang inovatif dan serba digital sehingga berdampak positif pada pengembangan keterampilan dan potensi siswa maupun guru. ${ }^{25}$

\section{Dampak Negatif}

Apa yang menjadi kekhawatiran para orangtua terhadap dampak negatif teknologi digital dalam hidup anak-anaknya memang tidaklah berlebihan, karena sama seperti terobosan teknologi lainnya, media atau gadget digital berbahaya bagi perkembangan nurani, moral, fisik, spiritual maupun kejiawaan mereka. Dampak negatifnya antara lain, adalah: pertama, games dan tayangan kekerasan. Kedua, pornografi dan pemangsa maya. Ketiga, keterbukaan yang berubah menjadi ketelanjangan. ${ }^{26}$ Dampak negatif dari pemangsa dan persahabatan lewat fasilitas umumnya dilakukan berupa: diiming-imingi dengan tawaran mendapatkan hadiah, menawarkan promosi kerjasama, memanipulasi seseorang lewat jejaring sosial, dan memanfaatkan kartu kredit lewat toko online. ${ }^{27}$ Hal yang senada terkait dampak negatif dalam hal degradasi karakter dan moral siswa akibat sisi lain dari perkembangan teknologi digital dinyatakan juga oleh Puspita Sari dan Jessica Elfani Bermuli. $^{28}$

\section{Konsep Parenting Sebagai Pendidikan Kristen Berdasarkan Alkitab}

Menghadirkan keturunan adalah rencana dan perintah Tuhan. Tuhan berfirman kepada Adam untuk beranak cucu dan bertambah banyak (Kej. 1:28).

${ }^{23}$ Anne Atkinson Parapak, Masa Muda Masa Indah Menghadapi Tantangan Bersama Tuhan, 1st ed. (Jakarta: Sripture Union Indonesia, 2019), 114-115.

24 Pratama, Cyber Smart Parenting.

25 Sioratna Puspita Sari and Jessica Elfani Bermuli, “Etika Kristen Dalam Pendidikan Karakter Dan Moral Siswa Di Era Digital [Christian Ethics in Teaching Character and Moral for Students in the Digital Era]," Diligentia: Journal of Theology and Christian Education 3, no. 1 (2021): 46-63.

26 Pratama, Cyber Smart Parenting.

27 Gunadi, Setiawan, and Mahanani, Memahami Remaja Dan Pergumulannya.

${ }^{28}$ Sari and Bermuli, "Etika Kristen Dalam Pendidikan Karakter Dan Moral Siswa Di Era Digital [Christian Ethics in Teaching Character and Moral for Students in the Digital Era]." 
Karena dosa, maka mendidik dan membesarkan anak merupakan tantangan berat. ${ }^{29}$ Perintah pertama Tuhan yang dicatat kepada manusia menjadi prinsip orangtua: "Beranakcuculah dan bertambah banyak." Manusia diperintahkan untuk mempunyai anak dan Tuhan menciptakan "manusia", baik laki-laki maupun perempuan, sehingga manusia dapat bertambah banyak melalui kesatuan seksual dalam ikatan perkawinan. Tuhan menciptakan Adam dan Hawa menurut gambar-Nya, dan anakanak mereka sebaliknya akan sesuai dengan rupa orangtuanya, kata "gambar" dan "rupa" berurusan dengan lebih dari hanya penampilan lahiriah; kata-kata itu berhubungan juga dengan kualitas-kualitas internal, dengan paling tidak mencakup tiga sasaran, yaitu: pertama, memproduksi sifat alami orang tua dalam diri anak. Kedua, memproduksi karakter orangtua dalam diri anak. Ketiga, memproduksi tingkah laku orangtua dalam diri anak. ${ }^{30}$

Orang tua adalah pemeran utama pendidikan anak, seperti diinstruksikan kepada orang tua dalam Ulangan 6:1-9. Perintah Tuhan untuk mendidik anak siang dan malam di segala tempat, berulang-ulang, supaya takut akan Tuhan dan berpegang pada perintah-Nya. Inti ajaran ini, hukum yang terutama adalah mengasihi Tuhan dengan segenap hati, jiwa dan akal budi. Tuhan sendiri mencontohkan bagaimana Yesus memperhatikan anak-anak dan memberkati mereka. Tuhan terus mengajar orangtua dan anak agar mengejar kekudusan dan kedewasaan iman dalam Kristus. ${ }^{31}$ Hal senada dinyatakan juga oleh Wadi dan Selfina, bahwa dalam membicarakan firman Tuhan kepada anak khususnya anak remaja membutuhkan waktu yang baik dan tepat. Namun, untuk mendapatkan waktu dari remaja di generasi ini sangat susah karena keseharian anak remaja akan dipenuhi dengan alatalat digital berupa hand phone, gad get, Notebook, Smartphone, dan lainnya. Selain itu, anak remaja juga akan banyak menghabiskan waktu bersama dengan teman-teman sebayanya di luar rumah. Membicarakan firman Tuhan kepada anak-anak bukan hanya ketika sedang berada di dalam rumah saja melainkan pada waktu bangun pagi, pada waktu bersama di luar rumah dan bahkan pada waktu akan tidur di malam hari. ${ }^{32}$ Terlebih ketika orangtua juga merealisasikan firman Tuhan, maka orang lain atau dalam hal ini anak dapat melihat teladan dan melihat perbuatan baik yang

${ }^{29}$ Jonathan L. Parapak and Tim LIFE, Growing Together 1 Seni Memperkaya Dan Memperindah Hidup Perkawinan, 3rd ed. (Jakarta: Literatur Perkantas, 2019), 34.

${ }^{30}$ Myles Munroe and David Burrows, Kingdom Parenting, 1st ed. (Jakarta: Immanuel, 2009), 7-

9.

${ }^{31}$ Jonathan L. Parapak and Tim LIFE, Growing Together 3: Memperkuat Dan Memperkaya Hidup Perkawinan, 1st ed. (Jakarta: Literatur Perkantas, 2018), 49-50.

32 Elsyana Nelce Wadi and Elisabet Selfina, "Peran Orang Tua Sebagai Keluarga Cyber Smart Dalam Mengajarkan Pendidikan Kristen Pada Remaja GKII Ebenhaezer Sentani Jayapura Papua," Jurnal Jaffray 14, no. 1 (2016): 77-92. 
mencerminkan Bapa, ${ }^{33}$ akan menjadi teladan atau panutan yang tepat bagi anak. Namun, jika kurangnya pengajaran dan pemahaman akan firman Tuhan serta kerinduan, lapar dan haus orang percaya dalam hal ini orang tua akan firman Tuhan tidak menjadi prioritas hidup, ${ }^{34}$ yang terjadi akan mengalami banyak kesulitan dalam mendidik.

Pendidikan anak dianggap Allah sangat penting oleh karena itu diminta supaya dilaksanakan berulang-ulang sampai mendarah daging dan menjadi bekal dalam segala aspek kehidupan. Pendidikan anak harus jelas tujuannya supaya anak takut akan Tuhan, mengasihi Tuhan, dan patuh pada perintah-perintah Tuhan. Mendidik anak sangat memerlukan keteladanan, oleh karena itu pendidikan yang benar harus berawal, berdasar dan berakar dalam keluarga. Amsal 1:8-10 menegaskan pentingnya anak mendengarkan nasihat ayah dan ibu. Efesus 6:1-4 mengajarkan untuk anak taat kepada orang tua, hormat kepada ayah dan ibu. Pada waktu yang sama ayah diperingatkan untuk tidak membangkitkan amarah di dalam hati anakanak, dan sebaliknya agar mendidik mereka dalam ajaran dan nasihat Tuhan. ${ }^{35}$ Semuanya diawali oleh keteladanan orangtua dan disiplin. Tidak ada cara mendidik anak seampuh keteladanan dan disiplin orang tua. ${ }^{36}$

\section{Orang Tua Sebagai Wakil Allah}

Orang Kristen memiliki satu tanggapan yang berbeda dengan orang nonKristen. Dalam Mzm. 103:13 dan Yes. 66:13 terlihat gambaran suatu prinsip yang sangat penting sekali, bahwa orangtua adalah wakil Allah di hadapan manusia, sehingga harus berhati-hati dalam mendidik anak. Anak adalah harta orangtua secara pribadi, yang juga harus dipertanggungjawabkan kepada Allah dan ini merupakan kewajiban yang bersifat kekal. Jikalau orangtua tidak menyadari prinsip ini, pastilah gagal menjadi orang tua. ${ }^{37}$

\section{Warisan Abadi}

Hampir semua orangtua pernah bergumul mengenai apa yang ingin diwariskan kepada anak cucu atau generasi penerus. Sebagian juga membesarkan anak untuk menjadi harapan pada masa tua atau usia emas. Kebanyakan orang tua akan mendambakan pendidikan yang baik, memperlengkapi anak cucu dengan kompetensi agar dapat berhasil, berkiprah di masa depan, dan menjadi generasi

33 Sri Lina Betty Lamsihar Simorangkir and Yonatan Alex Arifianto, "Makna Hidup Dalam Kristus Menurut Filipi 1:21 Dan Implikasinya Bagi Orang Percaya," CARAKA: Jurnal Teologi Biblika dan Praktika 1, no. 2 (2020): 228-242.

${ }^{34}$ Yonatan Alex Arifianto, "Kajian Biblikal Tentang Manusia Rohani Dan Manusia Duniawi," Jurnal Teruna Bhakti 3, no. 1 (2020): 12-24.

35 Parapak and LIFE, Growing Together 1 Seni Memperkaya Dan Memperindah Hidup Perkawinan. ${ }^{36}$ Andreas Christanday, Membangun Keluarga Yang Tak Terguncangkan, 1st ed. (Yogyakarta: Gloria Graffa, 2010), 18.

${ }^{37}$ Stephen Tong, Membesarkan Anak Dalam Tuhan, 7th ed. (Surabaya: Momentum, 2007), 5. 
penerus yang sukses secara ekonomi dan berprestasi dalam masyarakat. ${ }^{38}$ Banyak anak muda yang hidupnya hancur karena memperoleh kekayaan secara tiba-tiba, sedangkan mereka belum memiliki wawasan, bahkan karakter, mereka belum mampu mengelolanya. Selain itu, warisan uang juga tidak dapat bertahan dan tidak akan memberikan kebahagiaan yang sejati. Warisan rohani adalah satu-satunya warisan yang benar-benar layak ditinggalkan, warisan yang akan benar-benar memperkaya hidup anak-anak, membentuk karakter mereka, dan mempengaruhi hidup kekal mereka. Yaitu iman orangtua di dalam Yesus Kristus dan nilai-nilai rohani kerajaanNya yang kekal. Dengan kata lain, integritas dan hidup bersih orangtua menjadi berkat terbesar bagi keluarganya. ${ }^{39}$ Alkitab juga sebagai dasar dalam mendidik dan membimbing manusia pada kebenaran, agar berperilaku sesuai dengan norma-norma ajaran kristen. 40

\section{Mitos-Mitos Dalam Mendidik}

Ada beberapa mitos dalam mendidik yang harus selalu orangtua hindari ketika merencanakan cita-cita sebagai orangtua yang membangun dan komunikatif. Seperti mitos pada umumnya, mitos dalam mendidik diterima sebagai kebenaran. Padahal mitos tersebut tidak benar. Pertama, Keterlibatan penuh orangtua, orangtua yang baik harus melibatkan diri sepenuhnya dalam kehidupan anak-anaknya setiap hari. Kedua, Tanggung jawab penuh orangtua, keberhasilan atau kegagalan anak bergantung sepenuhnya pada orangtua. Ketiga, Sukacita penuh orangtua, menjadi orangtua merupakan pekerjaan yang sepenuhnya memperoleh ganjaran, dan bahwa Anda akan selalu bersukacita atas anak-anak. Gagasan ini hanya sebagian benar. Menjadi orangtua memang dapat memperoleh ganjaran dan menyenangkan. Tetapi, tidak selalu demikian. ${ }^{41}$

\section{Menjadi Orangtua Yang Penuh Pengertian}

Orangtua yang penuh pengertian sangat mempedulikan perilaku anakanaknya, namun orangtua seringkali begitu mudah dibuat bingung oleh perilaku anak-anaknya. Perhatian orangtua yang lebih mengutamakan prestasi anak dapat berdampak kepada pengabaian kepribadian anak. Bagi orangtua, apa yang mereka lakukan menjadi lebih penting daripada akan menjadi apa mereka kelak. Orangtua yang penuh pengertian cenderung lebih memerhatikan kondisi hati seorang anak. Perhatian yang diberikan lebih dari sekadar menyampaikan informasi yang benar,

${ }^{38}$ Jontahan L. Parapak, Growing Together 4: Usia Emas - Finishing Well, 1st ed. (Jakarta: Literatur Perkantas, 2020), 28.

${ }^{39}$ Steven J. Lawson, Warisan Abadi, 2nd ed. (Jakarta: Metanoia, 2005), 7-9.

${ }^{40}$ Mesirawati Waruwu, Yonatan Alex Arifianto, and Aji Suseno, "Peran Pendidikan Etika Kristen Dalam Media Sosial Di Era Disrupsi," JUPAK: Jurnal Pendidikan Agama Kristen 1, no. 1 (2020): $38-46$.

41 Wright, Menjadi Orangtua Yang Bijaksana. 
atau memberi tahu anak-anak tentang berbagai aktivitas yang harus mereka jauhi. Orangtua yang penuh pengertian tidak sekadar mendiskusikan dan membahas kebenaran; tetapi juga menunjukkan kekuatan, kebaikan, dan relevansi kebenaran itu. Untuk menjadi orangtua yang penuh pengertian harus membayar harga, karena pilihan untuk menjadi orangtua yang penuh pengertian akan mempengaruhi karier, waktu luang, hobi, dan persahabatan orangtua. ${ }^{42}$

\section{Tantangan dan Peluang Bagi Orangtua Menghadapi Generasi Digital}

Menjadi orangtua di masa kini mirip berlari marathon, butuh disiplin dan daya tahan yang tinggi. Komuputer, video game, bahkan televise mengungkap dunia yang kompleks, menggoda dan terkadang mengancam anak-anak berusia muda. Nilai-nilai etika yang berubah dan saling bertentangan menghinggapi dan membingunkan anakanak remaja. Norma sosial dan bentuk-bentuk keluarga bahkan membuat orang tua bingung akan apa yang benar dan dapat dipercaya. Semua tantangan ini telah memperbanyak kegelisahan yang sudah pasti dihadapi, ketika orang tua berusaha mendapatkan prinsip-prinsip yang pasti dan dapat diandalkan untuk menolong mereka menjadi orang tua yang baik sebagaimana mereka inginkan. ${ }^{43}$ Setiap orangtua yang ingin melindungi dan menavigasi anaknya dalam pelayarannya di dunia maya haruslah memahami dunia dimana dirinya bertumbuh dan dibesarkan. Meskipun kita berbagi hidup di planet yang sama, namun ada perbedan yang hakiki di antara dunia kita dan mereka, dan celah budaya antar generasi ini semakin melebar setiap harinya. Jika celah ini tidak dijembatani, maka komunikasi pun terputus, akibatnya efektivitas untuk memengaruhi mereka terimbas, dan sirnalah pengaruh orangtua dalam hidup mereka.

Generasi ini membutuhkan orangtua lebih dari sebelumnya untuk bisa memberikan navigasi dalam melayani dunia dan kehidupan yang demikian kompleks. ${ }^{44}$ Tantangan lain yang harus dihadapi para orangtua adalah kenyataan sifat penuh dosa manusia, baik dalam diri orangtua maupun anak-anak, sehingga tidak ada seorangpun dapat menjadi orangtua sempurna. Yang dapat dilakukan adalah mempelajari prinsip-prinsip Alkitab, berkomitmen untuk memberikan cara hidup yang benar dan menyerahkan kepada Tuhan untuk turut bekerja dalam kehidupan anak-anak melampaui apa yang dapat dilakukan orangtua. Tidak ada sekolah khusus untuk menjadi orangtua, sehingga orangtua harus belajar dan mencari banyak informasi terkait perkembangan anak dan permasalahannya melalui berbagai media dan sarana yang ada. Hal ini dapat membantu bagaimana orangtua dapat merencanakan sendiri pendidikan karakter anak-anak. Suami istri harus memiliki

${ }^{42}$ Wright and Oliver, Raising Kids To Love Jesus.

${ }^{43}$ Richard Patterson Jr, Mengasihi Anak Dengan Kasih Allah, 1st ed. (Jakarta: Literatur Perkantas, 2010), 4.

44 Pratama, Cyber Smart Parenting. 
kesepakatan dalam menetapkan tujuan pencapaian karakter anak yang diidamidamkan. Sebagai orangtua harus dapat mengendalikan dan melatih diri dalam melakukan fungsi parenting sesuai usia dan perkembangan kepribadian setiap anak, bersikap konsisten, tidak menyerah kepada tantangan untuk mulai melonggarkan atau menurunkan standar, mengasihi anak dengan setia sampai kesalahan atau kekeliruan yang dilakukan anak diperbaiki. Sebagai orangtua tentunya memiliki pergumulan yang berbeda untuk setiap tahapan perkembangan anak, salah satu kecemasan yang sangat kuat adalah ketika anak menginjak usia remaja. Kemajuan teknologi dan informasi selain membawa dampak positif juga memiliki dampak negatif, arus informasi yang sangat bebas dan mudah diperoleh oleh para remaja dapat mempengaruhi pola pikir. 45

\section{Aplikasi Parenting Orangtua Di Era Digital}

\section{Memiliki Visi Kerajaan Allah}

Mendidik anak di era digital yang penuh tantangan juga penuh peluang merupakan tugas yang amat berat. Derasnya arus nilai sekuler duniawi yang mengagungkan nikmatnya kekayaan, kekuasaan, seks, baik langsung maupun melalui media elektronik, merupakan masalah nyata dalam kehidupan orangtua dan anak-anak. Daya tarik berbagai ajaran dan falsafah humanistis juga menjadi bahaya yang selalu hadir dalam kehidupan anak-anak. Dalam suasana inilah, firman Allah menegaskan kepada orangtua pentingnya mendidik dan membekali anak dengan firman Allah dan kebenarannya serta mempraktikkan ajaran kasih dalam keluarga seperti yang dicontohkan Yesus dengan menyebut anak-anak sebagai pewaris kerajaan surga. Anak harus dididik dalam system keluarga yang telah diatur Tuhan. Orang tua perlu peka untuk mencari 'teachable moments' saat anak-anak terbuka untuk sharing tentang firman Allah dan pengalaman penerapan firman dalam kehidupan orangtua.

Keluarga adalah pelaku utama pendidikan, tetapi gaya otoriter dapat menimbulkan penolakan. Alangkah baiknya kalau dapat diciptakan suasana di mana anak-anak berani sharing pertanyaan dan pergumulan dengan orang tua yang adalah pendengar yang baik bukan hanya pengkhotbah ulung. Tentu, hal ini dilakukan dalam suasana saling mengasihi dan saling menerima. Anak hormat kepada orangtua, orangtua juga jangan membangkitkan amarah anak-anak. Pendidikan Kristen yang holistis, yang berpusat pada Kristus dan menekankan aspek spiritual, emosional, intelektual, sosial dan fisik, dimana keluarga adalah pemeran utama. Dengan dasar

45 Tri Astuti Yeniretnowati, “Karakter Anak Yang Prima," in Kataku, Kata Orangtuaku : 67 Kisah Pengalaman Anak Dan Orangtua Tentang Pendidikan Karakter, ed. Etiwati et al., 1st ed. (Jakarta: BPK PENABUR Jakarta, 2017), 210-211. 
yang kokoh dalam firman dan pendidikan berintegrasi, holistis, orangtua dapat mengantarkan anak menghadapi era digital dan berhasil menurup konsep Alkitab. ${ }^{46}$

Pendidikan dewasa ini menghadapi tantangan derasnya arus sekularisasi dan relativisme. Harus diyakini bahwa pendidikan Kristen yang holistis, berpusat kepada Kristus adalah pendidikan yang terbaik bagi anak-anak keluarga Kristen. ${ }^{47}$ Sehingga upaya yang dapat dilakukan oleh orangtua di antaranya: pertama, mengajarkan anak untuk mengasihi Allah dengan segenap hati, jiwa, dan hidup seturut dengan kebenaran Firman Allah. Kedua, mendidik anak sesuai dengan Firman Allah. Ketiga, memberikan pembelajaran pendidikan agama Kristen dalam keluarga. Keempat, konsisten dalam sikap, penghayatan dan pengalaman agama Kristen yang diimani. Kelima, konsisten menerapkan norma yang sesuai pendidikan agama Kristen. Keenam, membangun komunikasi yang baik dengan anak dan membimbing yang berorientasi pada kasih sayang. ${ }^{48}$

\section{Mendidik Anak Di Era Digital}

Sebagai orangtua yang bijaksana, ada beberapa tindakan yang perlu dilakukan untuk menyelamatkan anak dari godaan dan pengaruh pornografi, yaitu: pertama, memantau pergaulan anak, dengan cara mengetahui dan mengawasi pergaulan anak. Jika diperlukan menegur dan melarang anak untuk bergaul dengan teman-temannya yang berpotensi memberikan pengaruh buruk. Kedua, inisiatif menanyakan pergumulan anak terhadap godaan mengosumsi pornografi. Ada baiknya jika orangtua juga berbagi pergumulan pribadi sewaktu remaja. Ketiga, perlu mengajarkan disiplin diri. Jika sudah tahu film tertentu mengandung adegan seks, maka jangan dilihat, kalau memang tanpa sengaja menonton adegan seks, maka biasakan diri untuk menutup mata, atau biasakan diri mematikan atau mempercepat episode filmnya. Sebagai orangtua pun juga perlu melakukan disiplin seperti ini. Disiplin diri juga perlu diterapkan dalam hal meletakkan computer atau laptop. Peluang untuk melihat gambar dan film pornografi biasanya lebih besar ketika sedang sendirian. Keempat, mengingatkan anak tentang konsekuensi mencemarkan diri dengan pornografi. Kelima, perlu menitikberatkan nasihat pada yang hal positif, bukan yang negatif. Meski orangtua mengatakan tentang konsekuensi mencemarkan diri, namun titik berat penjelasan adalah pada memotivasi anak untuk hidup menyenangkan hati Tuhan, bukan menghindari hukuman Tuhan semata. ${ }^{49}$

Sikap orangtua terhadap tantangan negatif dari pemangsa dan persahabatan online yang melanda anak-anak, adalah: pertama, perlu berhati-hati dengan sikap

${ }^{46}$ Jonathan L. Parapak and Tim LIFE, Growing Together: Membangun Dan Memperkaya Keluarga Dalam Tuhan, 1st ed. (Jakarta: Literatur Perkantas, 2017), 35-36.

${ }^{47}$ Parapak and LIFE, Growing Together 3: Memperkuat Dan Memperkaya Hidup Perkawinan.

${ }^{48}$ Boiliu, "Pembelajaran Pendidikan Agama Kristen Dalam Keluarga Di Era Digital."

${ }^{49}$ Gunadi, Setiawan, and Mahanani, Memahami Remaja Dan Pergumulannya, 93-100. 
tamak. Sang pemangsa paham sekali kalau setiap orang memiliki sifat tamak dan memanfaatkannya. Kedua, mengajar anak untuk selalu mengecek ulang berita yang didapat dengan orang-orang yang dikenal baik. Alkitab selalu mengingatkan agar cerdik seperti ular dan tulus seperti merpati. Ketiga, anak-anak hendaknya mendengarkan nasihat orangtua. Kehati-hatian orangtua bukanlah pertanda kuno. Keempat, bagi orangtua harus hati-hati dan lembut kepada anak-anak. Kelima, sebagai orangtua jangan terlalu cepat menganggap semua fasilitas persahabatan online, seperti: Facebook, Twitter, Skype, Yahoo Messenger dan Whats App itu buruk sehingga meminta bahkan melarang anak-anak untuk tidak bersentuhan dengan semuanya. Padahal harus diakui bahwa dampak positif dari teknologi ini juga cukup banyak. Keenam, perlu mengingatkan anak-anak agar berhati-hati, dimana boleh berkenalan dengan melalui fasilitas online, namun jangan terburu-buru mengambil keputusan penting yang menyangkut hidup, seperti keputusan untuk berpacaran apalagi menikah. Ketujuh, memberikan panduan tentang rambu-rambu perkenalan dan persahabatam melalui fasilitas online, termasuk mengatakan kepada anak agar tidak mudah menceritakan hal-hal pribadi dan data keluarga kepada orang-orang yang dikenal lewat fasilitas online. Kedelapan, orangtua harus memastikan agar anakanak tidak kecanduan menggunakan fasilitas online. ${ }^{50}$

\section{Terus Bertumbuh Kembang Bersama Anggota Keluarga}

Menjadi orang tua lebih dari sekadar mengetahui sejumlah metode. Orang tua yang berpengetahuan baik akan meramu dengan sempurna keterampilan menjadi orang tua dengan banyak doa, perenungan Firman Allah, pertobatan setiap hari, kekayaan kasih, sukacita, dan segudang kasih sayang. ${ }^{51}$ Tidak ada orangtua yang sempurna. Seandainya ada, tentu anak-anak tidak memerlukan Tuhan. Akan tetapi, karena orangtua tidak sempurna, orangtua dan anak-anak sangat membutuhkan Tuhan, lagi, dan lagi. ${ }^{52}$ Mendidik anak adalah sebuah keunikan tanggung jawab, yaitu sebuah pelayanan kepada anak seutuhnya, yakni secara jasmani, emosi, intelektual, sosial dan spiritual. Mendidik anak membutuhkan pengakuan bahwa bukan orangtua yang memiliki anak-anak, mereka hanya dipercayakan sehingga membutuhkan keterbukaan yang tidak menguasai dan mengendalikan. Mendidik anak adalah sebuah kerja sama dengan Tuhan. Anak bukanlah reflika diri orangtua. Mereka akan membuat keputusan-keputusan iman dengan cara yang unik bagi mereka. Mereka seperti semak mawar.

50 Ibid., 105-119.

${ }^{51}$ Henry Brandt and Kerry L. Skinner, Berbahagia Bersama Anak-Anak Terkasih, 1st ed. (Jakarta: Yayasan Komunikasi Bina Kasih/OMF, 2007), 25. 2009), 1.

52 Anne Neufeld Rupp, Tumbuh Kembang Bersama Anak, 1st ed. (Jakarta: BPK Gunung Mulia, 
Orangtua memelihara, menyirami, bahkan menyediakan lampu, tetapi pada akhirnya mereka akan berbunga jika mereka sudah siap, ketika mereka disentuh oleh tangan Tukan Taman yang kekal. ${ }^{53}$ Mossholder menyatakan bahwa ada sepuluh keperluan terbesar anak, yang jika orangtua gagal memenuhinya, maka anak akan cenderung memberontak, yaitu: pertama, diperlukan untuk ikatan: orangtua yang saling mengasihi, bukan menciptakan peperangan. Kedua, dibutuhkan untuk ikatan: berilah kasih saying yang sama kepada seluruh anak. Ketiga, diperlukan untuk ikatan: orangtua yang jujur. Keempat, perlunya ikatan: orangtua yang jelas saling mengasihi; Kelima, yang diperlukan untuk ikatan: kegembiraan dan persekutuan di antara orangtua dan anak-anak. Keenam, yang diperlukan untuk ikatan: Perlakukan anakanak teman Anda sebagai pengunjung yang diterima di rumah. Ketujuh, perlu untuk ikatan: selalu menjawab pertanyaan-pertanyaan anak-anak. Kedelapan, perlu untuk ikatan: jangan pernah mengoreksi atau menghukum anak-anak Anda di hadapan orang lain. Kesembilan, perlu untuk ikatan: berkonsentrasilah pada hal-hal yang baik yang ada dalam diri anak Anda. Jangan melebih-lebihkan kegagalan-kegagalannya.; Kesepuluh, perlu untuk ikatan: Konsistenlah di dalam kasih sayang dan suasana hati. ${ }^{54}$

\section{Mengenali Perbedaan dan Perkembangan Anak Sejak Dini}

Penelitian ilmiah berkali-kali menunjukkan bahwa setiap bayi menunjukkan perbedaan kepribadian yang signifikan sejak lahir. Bayi dilahirkan dengan keunikan karakteristik temperamen, corak perilaku, dan cara merespons rangsangan dari luar. Karena setiap bayi memiliki cara unik dalam berinteraksi dengan lingkungannya, orangtua harus memahami dan menyambut baik keunikan bayi tersebut. 55 Hal ini dipertegas dengan adanya dua pandangan bertentangan yang sejuah ini dijadiakan acuan utama dalam konsep ilmu perkembangan anak, yaitu: pertama, anak sebagai kertas putih, yang perkembangannya akan sangat ditentukan oleh stimulasi lingkungannya dimana anak itu berada. Kedua, anak sebagai pewaris bakat-bakat dan kecenderungan orangtuanya. Pembentukan jati diri anak merupakan warisan genetis dari orangtua. ${ }^{56}$

Kedua pandangan bertentangan di atas terjembatani dengan adanya penemuan baru di bidang neurologi yang populer sejak 1997, mengenai perkembangan otak manusia sejak dalam kandungan. Saat dilahirkan, otak seorang bayi berisi 100 miliar neuron atau kurang lebih sebanyak bintang-bintang di system Galaxy Bima Sakti.

\footnotetext{
53 Rupp, Tumbuh Kembang Bersama Anak.

54 Roy Moosholder, Cara Mendidik ANak Di Tengah Lingkungan Yang Makin Sekular, 3rd ed. (Yogyakarta: Andi Offset, 2006), 175.

${ }^{55}$ H. Norman Wright, Cara Bicara Orangtua Yang Didengarkan Anak, 2nd ed. (Yogyakarta: Gloria Graffa, 2012), 14.

56 Tri Budiardjo, Pelayanan Anak Yang Holistik, 1st ed. (Yogyakarta: Andi Offset, 2011), 15-16.
} 
Ketika bayi lahir, otak telah menata sirkuitnya sesuai dengan prakiraan yang terbaik mengenai apa yang akan diperlukan bagi penglihatan, bahasa, emosi, dan apa saja. ${ }^{57}$

Hal penting dari pengetahuan ini semakin memperkuat pemahaman orang tua betapa pentingnya pengasuhan anak sejak dini, sehingga dapat menyusun dan memilih kegiatan-kegiatan yang terencana, teratur, dan terkoordinasi dalam lingkup kelompok bermain, pra sekolah, dan penitipan anak memiliki pengaruh sangat besar terhadap tumbuh kembang anak. ${ }^{58}$ Tahapan tumbuh kembang anak menjadi perhatian yang sangat penting bagi berbagai pihak termasuk orang tua Kristen dalam memilih konten-konten yang patut dilihat dan didengar di era digital ini.

Peranan orangtua dalam perkembangan anak menurut seorang ahli perkembangan anak dan psikologi yaitu, Gunarsa adalah meliputi empat peran, yaitu: pertama, sebagai orangtua, membesarkan, merawat, memelihara, dan memberikan anak kesempatan berkembang. Kedua, sebagai guru, mengajarkan ketangkasan motorik, keterampilan melalui latihan-latihan dan mengajarkan peraturan-peraturan tata cara keluarga, tatanan lingkungan masyarakat. Ketiga, sebagai tokoh teladan, menjadi tokoh yang ditiru pola tingkah lakunya, cara berekspresi, cara berbicara. Keempat, sebagai pengawas, memperhatikan dan mengamati tingkah laku anak. 59

\section{Disiplin Anak ke Arah yang Seharusnya}

Amsal 22:6 menekankan untuk mendidik orang muda menurut jalan yang patut dan benar. Barangkali orangtua telah mendisiplinkan anak-anak di jalan yang seharusnya mereka tempuh, tapi mereka meninggalkan jalan tersebut. Jangan sertamerta berasumsi bahwa pembangkangan anak-anak itu sebagai akibat dari kesalahan orangtua. Namun, cobalah pahami apa yang diajarkan Alkitab, yakni ada tiga faktor yang menentukan bagaimana seorang anak itu jadinya: pertama, orangtua bertanggung jawab untuk secara rendah hati memuliakan Tuhan dan mematuhi dengan penuh keimanan Sabda Allah dalam mendisiplinkan anak-anak. Kedua, anakanak bertanggung dengan kerendahan hati memuliakan orangtuanya dan Tuhan dengan mematuhi penuh keimanan. Ketiga, Allah adalah pengendali yang berkuasa penuh dalam kehidupan para orangtua dan anak-anak, mengarahkan mereka sesuai dengan tujuan-Nya yang baik. ${ }^{60}$

\section{Kembangkan Bahasa Cinta}

Chapman mengidentifikasi lima cara orangtua mengekspresikan dan menerima cinta. Ada satu aspek lagi dari keunikan seorang anak, yaitu bagaimana

${ }^{57}$ Ibid., 16-17.

${ }^{58}$ Ibid., 18-19.

49.

59 Yulia Singgih D. Gunarsa, Asas-Asas Psikologi Keluarga Idaman, 1st ed. (Jakarta: Libri, 2012),

${ }^{60}$ Elyse Fitzpatrick, Jim Newheiser, and Laura Hendrickson, When Good Kids Make Bad Choices, 1st ed. (Jakarta: TransMedia, 2006), 17-18. 
mereka mengekspresikan dan menerima cinta. Seorang anak biasanya mempunyai kesukaan atau dua bahasa cinta ini baik cara cinta diekspresikan maupun diterima, yaitu: Pertama, waktu bersama, menyukai waktu bersama orangtua yang berpusat dan tidak terganggu. Kedua, pemberian hadiah, suka memberi dan menerima hadiah. Ketiga, tindakan melayani, suka melakukan sesuatu untuk orang lain, memberikan waktu dan tenaga untuk menunjukkan cinta. Keempat, kata-kata yang menguatkan, suka memberi dan menerima kata-kata pujian, dukungan dan menguatkan. Kelima, sentuhan fisik yang tepat, butuh pelukan, tepukan dilengan, genggaman tangan, dan lainnya untuk membuat anak mengetahui bahwa dia dicintai. ${ }^{61}$

Orang dewasa berorientasi verbal, sedangkan anak-anak berorientasi perilaku. Orang dewasa bergelut dengan symbol, sintaksis, dan konsep-konsep teoritis lebih daripada yang orangtua sadari. Anak-anak mengalami dunia dalam apa yang mereka lihat, apa yang mereka rasakan, dan apa yang mereka sentuh. Solusinya ketika ada dua bahasa berbeda, orangtua perlu belajar bagaimana mengungkapkan cinta dalam sebuah bahasa yang sudah siap dipahami oleh anak. Ada tiga alasan utma orangtua harus pintar menterjemahkan cinta dalam tindakan nyata, yaitu: pertama, menggunakan perbuatan untuk menyatakan cinta, demikianlah itu satu-satunya cara untuk mengkomunikasikan cinta dengan jelas. Kedua, harus menggunakan perbuatan untuk membuktikan cinta. Tidak ada kaitannya dengan persepsi anak-anak, ini terkait persepsi manusia. Ketiga, harus menggunakan perbuatan untuk mempromosikan cinta orangtua. Faktanya banyak orang tidak tahu bagaimana menunjukkan perasaan karena orangtua sendiri tidak dilatih untuk melakukan itu oleh pendahulunya. Banyak orangtua hidup dalam kehidupan dengan tangki emosi yang kosong, dan meneruskannya kepada generasi berikutnya. ${ }^{62}$

\section{Kesimpulan}

Peran orangtua yang berhasil di era digital ini adalah orangtua mau belajar untuk melindungi dan menavigasi anaknya yang sedang ada dalam era digital dengan cara yang mampu menghadirkan keluarga yang adaptif terhadap perubahan teknologi dan informasi, yang mengenali dan memahami pikiran dan perasaan setiap anaknya dengan baik serta mengasuhnya dengan menerapkan bahasa cinta dalam berkomunikasi. Kehidupan keluarga Kristen adalah tentang pertanggungjawaban iman, dan memerankan peran sebagai orangtua merupakan sebuah misi pertanggungjawaban kehidupan dan mandat budaya dari Allah. Tugas orangtua adalah sebuah perjalanan iman, sehingga orangtua dapat memiliki pengharapan karena anugerah Allah yang besar, dan sebagai hasilnya orangtua memiliki kasih,

${ }^{61}$ Larry Keefauver, Anda Dan Harta Terbesar Anda, 1st ed. (Semarang: Media Injil Kerajaan, 2002), 42.

62 Ross Campbell and Rob Suggs, How To Really Parent Your Child, 1st ed. (Jakarta: Visimedia, 2006), 22-24. 
sukacita dan ketenangan hati serta pikiran yang dalam sebagai dasar dalam mendidik dan mewariskan iman kepada generasi penerus. Untuk itu paling tidak dua hal penting yang harus ditonjolkan dan menjadi andalan orangtua dalam menjalankan peran parentingnya berdasarkan perspektif pendidikan Kristen, yaitu: menjadi model teladan yang mencerminkan prinsip-prinsip kehidupan berdasarkan Alkitab dan yang kedua adalah membangun hubungan relasi yang baik dan kuat dengan anakanak.

Seiring dengan perkembangan zaman yang terus berubah dengan sangat cepat, maka sebagai orang tua juga harus makin keras, makin cerdas, makin mawas, dan makin tuntas menghadapi persoalan tantangan era digital yang memengaruhi anakanak yang ada dalam era digital ini dengan memperhatikan beberapa hal praktis yang disarankan oleh para ahli teknologi dan informasi, yaitu: orangtua perlu memantau pergaulan anak secara berkala, lebih inisiatif untuk menanyakan pergumulan anak terhadap godaan negatif dari penggunaan media digital, perlu mengajarkan disiplin diri, perlunya dengan terus-menerus mengingatkan anak tentang konsekuensi mencemarkan diri dengan hal-hal negatif akibat penggunaan media digital, perlu menitikberatkan nasihat pada yang hal positif, bukan yang negatif, perlu waspada dengan sikap tamak karena tergiur berbagai tawaran dari media digital, mengajar anak untuk selalu mengecek ulang berita yang didapat agar tidak salah, menyediakan manual panduan tentang rambu-rambu penggunaan media digital yang baik dan bagaimana berteman melalui fasilitas online, serta sebagai orangtua juga harus memastikan agar anak-anak tidak kecanduan menggunakan fasilitas media digital.

\section{Rujukan}

Amir, Hamzah. Metode Penelitian Kepustakaan. 1st ed. Batu: Literasi Nusantara, 2020. Arifianto, Yonatan Alex. “Kajian Biblikal Tentang Manusia Rohani Dan Manusia Duniawi." Jurnal Teruna Bhakti 3, no. 1 (2020): 12-24.

- - - "Pentingnya Pendidikan Kristen Dalam Membangun Kerohanian Keluarga Di Masa Pandemi Covid-19." REGULA FIDEI: Jurnal Pendidikan Agama Kristen 5, no. 2 (2020): 94-106.

Arniwati, and R. Budyarto. Dampak Teknologi Terhadap Kehidupan Rohani Anak Dan Remaja. 1st ed. Malang: Gandum Mas, 2012.

Boiliu, Fredik Melkias. “Pembelajaran Pendidikan Agama Kristen Dalam Keluarga Di Era Digital." TE DEUM (Jurnal Teologi Dan Pengembangan Pelayanan) 10, no. 1 (2020): 107-119.

Brandt, Henry, and Kerry L. Skinner. Berbahagia Bersama Anak-Anak Terkasih. 1st ed. Jakarta: Yayasan Komunikasi Bina Kasih/OMF, 2007.

Budiardjo, Tri. Pelayanan Anak Yang Holistik. 1st ed. Yogyakarta: Andi Offset, 2011. Campbell, Ross, and Rob Suggs. How To Really Parent Your Child. 1st ed. Jakarta:

Visimedia, 2006. 
Christanday, Andreas. Membangun Keluarga Yang Tak Terguncangkan. 1st ed.

Yogyakarta: Gloria Graffa, 2010.

Fitzpatrick, Elyse, Jim Newheiser, and Laura Hendrickson. When Good Kids Make Bad

Choices. 1st ed. Jakarta: TransMedia, 2006.

Gunadi, Paul, Andrew Abdi Setiawan, and Lortha Gb. Mahanani. Memahami Remaja Dan Pergumulannya. 2nd ed. Bandung: Visipress, 2015.

Gunarsa, Ny. Singgih D., and Singgih D. Gunarsa. Psikologi Untuk Keluarga. 17th ed. Jakarta: BPK Gunung Mulia, 2009.

Gunarsa, Singgih D. Dari Anak Sampai Usia Lanjut: Bunga Rampai Psikologi

Perkembangan. 3rd ed. Jakarta: BPK Gunung Mulia, 2009.

Gunarsa, Yulia Singgih D. Asas-Asas Psikologi Keluarga Idaman. 1st ed. Jakarta: Libri, 2012.

Haryati. "Potret Anak Indonesia: Sebuah Tantangan Dan Peluang." In Teologi Anak

Sebuah Kajian, edited by Tim KTAK Anak Bersinar Bangsa Gemilang Jaringan

Peduli Anak Bangsa. 1st ed. Jakarta: Literatur Perkantas, 2018.

Jr, Richard Patterson. Mengasihi Anak Dengan Kasih Allah. 1st ed. Jakarta: Literatur Perkantas, 2010.

Keefauver, Larry. Anda Dan Harta Terbesar Anda. 1st ed. Semarang: Media Injil Kerajaan, 2002.

Lawson, Steven J. Warisan Abadi. 2nd ed. Jakarta: Metanoia, 2005.

Lubis, Hairani, Afif Husniyatur Rosyida, and N H Solihatun. “Pola Asuh Efektif Di Era Digital." Plakat 1, no. 2 (2019): 102-109.

Moosholder, Roy. Cara Mendidik ANak Di Tengah Lingkungan Yang Makin Sekular. 3rd ed. Yogyakarta: Andi Offset, 2006.

Munroe, Myles, and David Burrows. Kingdom Parenting. 1st ed. Jakarta: Immanuel, 2009.

Ndraha, Roswitha, and Julianto Simanjuntak. Tidak Ada Anak Yang Sulit. 1st ed. Yogyakarta: Andi Offset, 2009.

Parapak, Anne Atkinson. Masa Muda Masa Indah Menghadapi Tantangan Bersama

Tuhan. 1st ed. Jakarta: Sripture Union Indonesia, 2019.

Parapak, Jonathan L., and Tim LIFE. Growing Together : Membangun Dan Memperkaya Keluarga Dalam Tuhan. 1st ed. Jakarta: Literatur Perkantas, 2017.

- - - . Growing Together 1 Seni Memperkaya Dan Memperindah Hidup Perkawinan. 3rd ed. Jakarta: Literatur Perkantas, 2019.

- - - Growing Together 3: Memperkuat Dan Memperkaya Hidup Perkawinan. 1st ed. Jakarta: Literatur Perkantas, 2018.

Parapak, Jontahan L. Growing Together 4: Usia Emas - Finishing Well. 1st ed. Jakarta: Literatur Perkantas, 2020.

Pratama, Hellen Chou. Cyber Smart Parenting. 1st ed. Bandung: Visi Anugerah Bandung, 2012. 
Rupp, Anne Neufeld. Tumbuh Kembang Bersama Anak. 1st ed. Jakarta: BPK Gunung Mulia, 2009.

Sari, Sioratna Puspita, and Jessica Elfani Bermuli. “Etika Kristen Dalam Pendidikan

Karakter Dan Moral Siswa Di Era Digital [Christian Ethics in Teaching

Character and Moral for Students in the Digital Era]." Diligentia: Journal of

Theology and Christian Education 3, no. 1 (2021): 46-63.

Simorangkir, Sri Lina Betty Lamsihar, and Yonatan Alex Arifianto. "Makna Hidup

Dalam Kristus Menurut Filipi 1:21 Dan Implikasinya Bagi Orang Percaya."

CARAKA: Jurnal Teologi Biblika dan Praktika 1, no. 2 (2020): 228-242.

Suhartin, R.I. Smart Parenting. 1st ed. Jakarta: Libri, 2010.

Tong, Stephen. Membesarkan Anak Dalam Tuhan. 7th ed. Surabaya: Momentum, 2007.

Wadi, Elsyana Nelce, and Elisabet Selfina. "Peran Orang Tua Sebagai Keluarga

Cyber Smart Dalam Mengajarkan Pendidikan Kristen Pada Remaja GKII

Ebenhaezer Sentani Jayapura Papua." Jurnal Jaffray 14, no. 1 (2016): 77-92.

Waruwu, Mesirawati, Yonatan Alex Arifianto, and Aji Suseno. "Peran Pendidikan

Etika Kristen Dalam Media Sosial Di Era Disrupsi." JUPAK: Jurnal Pendidikan

Agama Kristen 1, no. 1 (2020): 38-46.

Wright, H. Norman. Cara Bicara Orangtua Yang Didengarkan Anak. 2nd ed.

Yogyakarta: Gloria Graffa, 2012.

- - - . Menjadi Orangtua Yang Bijaksana. 2nd ed. Yogyakarta: Andi Offset, 1991.

Wright, H. Norman, and Gary J. Oliver. Raising Kids To Love Jesus. 3rd ed.

Yogyakarta: Gloria Graffa, 2013.

Yeniretnowati, Tri Astuti. “Karakter Anak Yang Prima.” In Kataku, Kata Orangtuaku :

67 Kisah Pengalaman Anak Dan Orangtua Tentang Pendidikan Karakter, edited by

Etiwati, Judha Semal Sinulingga, Hendriana Day, and Harun D. Simarmata.

1st ed. Jakarta: BPK PENABUR Jakarta, 2017.

Zaluchu, Sonny Eli. “Struktur Artikel Untuk Jurnal Ilmiah Dan Teknik

Penulisannya." In Strategi Menulis Jurnal Untuk Ilmu Teologi, edited by Sonny

Eli Zaluchu, 1-21. 1st ed. Semarang: Golden Gate Publishing Semarang, 2020. 